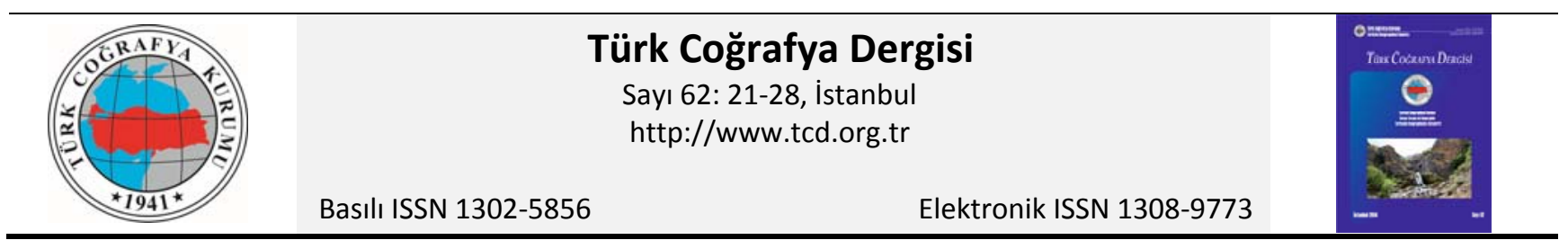

Hakemli Makale

Reviwed Article

\title{
Reyhanlı İlçesi topraklarında tuzlanma problemi
}

\author{
Salinization problem in soil of Reyhanlı district
}

\begin{abstract}
Ahmet ATASOYa, Reşat GEÇEN ${ }^{a}$
a) Mustafa Kemal Üniversitesi, FenEdebiyat Fakültesi, Coğrafya Bölümü.

\section{ÖZ}

Amik Ovası, coğrafi potansiyeli bakımından çevresindeki morfolojik ünitelere göre daha elverişli bir konumdadır. Ancak yoğun tarımsal faaliyetlerden kaynaklanan yanlış arazi kullanımı çok çeşitli sorunlara yol açmaktadır. Bu problemlerin başında tuzlanma gelmektedir. Çalışmada, toprak tuzluluğu ölçülerek ve analiz edilerek Reyhanlı ilçesi'ndeki tuzlanma problemi incelenmiştir. Çalışmaya başlamadan önce toprak tipleri esas alınarak, ölçümün yapılacağı noktalar belirlenmiştir. Daha sonra gerekli koşullar sağlanmış ve arazi çalışmasına başlanmıştır. Yağışlı havalardan hemen sonra araziye çıkılarak, 214 noktada toprağın iletkenliği tespit edilmiştir. Ölçüm sonuçları Coğrafi Bilgi Sistemleri (CBS) ortamına aktarılarak Kriging yöntemi ile enterpolasyon yapılmış ve sahanın tuzluluk sınıfları belirlenmiştir. Buna göre tuzluğu $\mathbf{4}$ mmos'un üzerinde olan 10 $\mathbf{~ k m}^{2}{ }^{\prime}$ lik alan tespit edilmiştir. Bu tespitlere bağlı olarak tuzluluğun sebepleri araştırılmış ve bunlara yönelik çözüm önerileri sunulmuştur.

Anahtar Kelimeler: Tuzlanma, toprak, ziraat coğrafyası, CBS.
\end{abstract}

Geliş/Received: 03.02.2013 Kabul /Accepted: 28.02.2014

Sorumlu yazar/Corresponding author (A. ATASOY) aatasoy@mku.edu.tr

\section{ABSTRACT}

Amik Plain has high geographical potential of Turkey in terms of agricultural activity. However depend on intense agricultural activity and mis land use several problems have been occurred. The main one is salinization problem. This study focuses on soil salinization problem in Reyhanlı district by measurement and analyses methods. Firstly the location points of measurement have been determined based on soil types. Then the field study and measurements have been taken. Electrical conductivity of soil has been measured on 214 locations by using a hand-held sensor device after rainy days. These measured values have been inputted in Geographic Information Systems (GIS) and by using Kriging interpolation method the salinity classes of area were identified. Accordingly, in study area $10 \mathrm{~km}^{2}$ area was determined having more than $4 \mathrm{mmos}$ value. Finally the reasons of salinization have been investigated and the recommendations have been presented.

Keywords: Salinization, soil, agricultural geography, GIS.

\section{GiRiş}

Türkiye'de yapısal özelliklerin, rölyef şekillerin, iklim ve vejetasyon gibi faktörlerin sık sık değişmesine bağı olarak toprak grupları açısından büyük bir çeşitlilik ortaya çıkmıştır. Bununla birlikte topraklarımızın bazı sorunları vardır. Bunlardan birini de tuzlanma oluşturmaktadır. Normal aralığın dışında suda çözülebilir iyon konsantrasyonuna sahip olan topraklara tuzlu topraklar, fazla miktarda $\mathrm{Na}^{+}$ içeren toraklara sodik topraklar ve her ikisini birden içerenlere ise tuzlu sodik toprak olarak adlandırılmaktadır (Akalan, 1992). Kurak ve yarı kurak sahalarda yer yer dış drenaja bağlantısı olmayan birçok kapalı havza ve depresyon bulunmaktadır. Bu sahalara, çözelti halindeki malzeme mevsimlik akarsular tarafından taşınmaktadır. Böylece oluşan su birikintileri buharlaşma ile ortadan kalkerken, geride tuz çökelleri kalmaktadır (Atalay, 2006).
Eğer tuz çökelleri tarım arazilerinde birikirse, tarımsal üretimin azalmasına neden olacaktır.

Toprak, bir ülkenin en önemli kaynaklarından birini meydana getirmektedir. Elverişli iklim koşullarının bulunduğu sahalarda yer alan toprakların tarım potansiyeli çok daha yüksek olmaktadır. Buna ilaveten sulamayla tarımsal arazilerin verimi daha da artmaktadır. Ancak suyun bitkiye sağladığı fayda yanında sulama sonucu toprakta bazı zararlar da ortaya çıkmaktadır. Bazı hallerde kontrolsüz yapılan sulama faaliyetleri sonucunda geniş tarım arazileri çorak, tuzlu topraklar haline gelebilmektedir (Yılmaz, 2010). Tuzlanma tarım topraklarını tehdit eden önemli çevre sorunlarından biridir. Tarım topraklarının tuzlanması, hem toprakların üretim dışı kalmasına hem de önemli bir doğal 
kaynak olan topraklarımızın elden çıkmasına neden olmaktadır (Yılmaz, 2010).

Türkiye'de tuza karşı dayanıklı olan bitkilerin yetişmesine imkân veren hafif tuzlu toprakların kapladığı alan 614.657 ha. (\% 0,8), üretime imkân vermeyen tuzlu topraklar 504.603 ha $(\% 0.6)$, sodik topraklar 8.641 ha $(\% 0.01)$, hafif tuzlu-sodik topraklar 123.863 ha $(\% 0.2)$, tuzlu sodik topraklar 264.956 ha $(\% 0,3)$ olmak üzere toplam 1.518 .722 ha. civarındadır (Akalan, 1992).

Akdeniz Bölgesi'nde tuzluluğu yüksek olan araziler 20.4217 ha'dır (Anonim, 1973). Dinç ve arkadaşlarının 1985 yılında Çukurova'da yaptığı bir çalışmada Çukurova'nın \%17.9'una karşılık gelen 60.898 ha tuzlu alan tespit ediliştir (Dinç vd., 1990). Dougherty ve Hall'a göre ülkemizde de tuzlu sahaların genişlemesinde etkili olan faktörlerin başında yanlış sulama teknikleri gelmektedir (Dougherty ve Hall,1995). Topraktan yıkanıp uzaklaşmayan tuzlar, aşırı ve bilinçsiz sulama nedeniyle önemli bir çevre sorunu yaratmaktadır.

Reyhanlı, toprak problemlerinin yaygın olduğu ilçemizden biridir. Bu problemlerin başında çeşitli nedenlere bağlı olarak ortaya çıkan tuzluluk gelmektedir. Sahada yeraltı suyunun kullanımı ve arazinin morfolojik özelliklerine bağlı olarak tuzluluk yayılma eğilimi göstermektedir. Eğer tuzlanmaya karşı etkili bir mücadele yapılmazsa toprakta tuzluluk artacak ve zamanla toprak verimliliğini yitirecektir. İşte bu nedenle Reyhanlı'da tuzluluğun yükseldiği araziler tespit edilmiş ve buna yönelik çözüm önerileri sunulmuştur.

Toprağın tuzlanması üzerinde doğal ve beşeri faktörlerin etkisi vardır. Beşeri faktörler arasında arazi kullanımı başta gelmektedir. Doğal ortam özellikleri arasında ise yapısal ve iklim özellikleri ilk sırada gelmektedir. Burada bu özelliklere kısaca değinilecektir.

Akdeniz Bölgesi'nin Adana Bölümü'nde yer alan Hatay İli'ne bağlı ve 362 km²lik bir (Şekil 1) alandan oluşan Reyhanlı illçesi'nde tuzluluğu 2 mmos'un üzerinde çok geniş alanlar bulunmaktadır.

Amik Gölü, geniş tarım arazilerini kazanmak amacıyla açılan drenaj kanallarıyla 1955-1975 yılları arasında ortadan kaldırılmıştır. Ancak yoğun bir şekilde sürdürülen zirai faaliyetler drenaj kanallarının tıkanmasına yol açmaktadır. Asi ile birlikte diğer akarsuların taştığı dönemlerde kanalların da tıkanık olmasından dolayı çok geniş tarım arazileri taşkına uğramaktadır.

Eski Amik Gölü'nün aynası dışında kalan ve dış drenaja kapalı olan polye tabanı Reyhanlı'nın kuzeydoğusundadır. Amik Ovası'na göre 50-100 m daha yüksekte bulunan polyenin batısı dışında kalan bütün çevrelerinde yüksek dağlar vardır. Bu dağlardan kaynaklanan akarsuların çoğu polye tabanına ulaşmaktadır. Akarsularla polye tabanına kadar taşınan tuzlar şiddetli buharlaşmanın sürdüğü yaz aylarında çökelmektedir.

Çoğunlukla alüvyal topraklardan meydana gelen Reyhanlı İlçesi verimli tarım arazilerine sahiptir. Ancak sulama suyunun yetersiz olması zorunlu olarak yer altı sularından

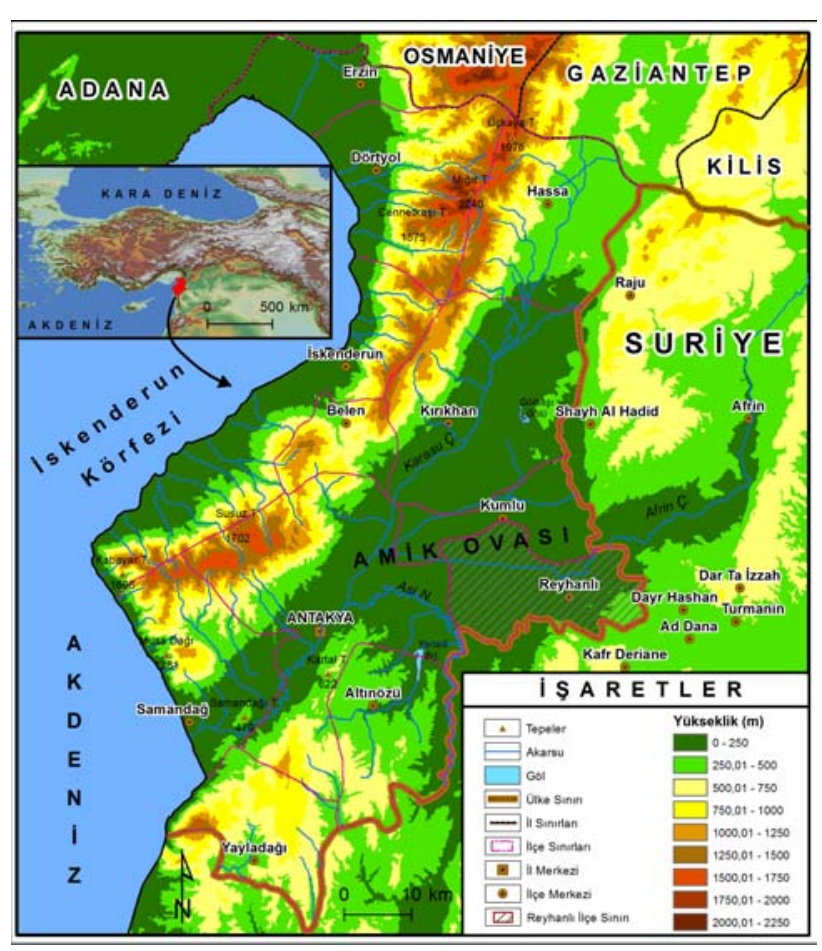

Şekil 1. Araştırma alanının coğrafî konumu.

Figure 1. Location of study area.

faydalanmayı gerektirmiştir. Bu zorunluluk topraklarda tuzluluğun artmasına yol açmaktadır. Çünkü yeraltı suları, yarı kurak bir iklim sahasından yerüstü ve yeraltı kaynaklarla beslenmesi ve bu suların eski bir göl tabanında birikmesi nedeniyle tuzluluğu yüksek olan suları oluşturmaktadır. Yazın kuyularla yeraltı sularına aşırı yüklenilmesiyle birlikte şiddetli buharlaşmanın da etkisiyle yeraltı su seviyesi alçalırken, kışın düşen yağışlarla yükselerek yüzeye kadar çıkmaktadır. Yeraltı sularının yıllık değişimi ve sulama suyu olarak kullanılması gibi nedenlerle toprakta tuz konsantrasyonu artmaktadır. Böylece alüvyal toprakların verimi her geçen gün azalmaktadır. Öte yandan verimi arttırmak amacıyla aşırı bir biçimde gübre ve tarımsal ilaçlar kullanılmaktadır. Tuzlanmanın yaygınlaşmasını önlemek amacıyla sahanın drenaja açılması gerekmektedir. Diğer taraftan tıkanan drenaj kanallarının sık sık temizlenmesi sağlanmalıdır. Bu uygulamalar yapılmadığı taktirde çok daha kötü sonuçlar ortaya çıkacaktır. Çünkü tuzlanan toprağı yeniden tarıma kazandırmak hem pahalı hem de zaman alan bir iştir.

Reyhanlı'da Eosen'den Kuvaterner'e kadar olan zaman aralığında oluşmuş, litolojik birimler görülmektedir. Bunlar Okçular, Sofular, Tepehan Formasyonu ile Kuvaterner alüvyonlarıdır (Şekil 2). Okçular Formasyonu çörtlü ve detritik kalkerden oluşmaktadır. Eosen yaşı bu birimler Reyhanlı'nın güneyinde görülmektedir (Yıldız ve Taptık, 2003).

Miyosen yaşlı Sofular Formasyonu, Reyhanlı'nın doğusunda, Suriye sınırından itibaren yüzeylenmekte ve Cilvegözü, Oğulpınarı, Kuşaklı, Alakuzu köylerine doğru genişlemektedir. Çakıryiğit Köyü’nden itibaren Reyhanlı'ya doğru, alüvyal yelpazesi taraçasının etrafını kuşatacak 
şekilde uzanmaktadır (Atasoy, 2012). Yapılan incelemeler sonucunda bu formasyonun üst kesimlerinde kil ve alt kesimlerinde kum

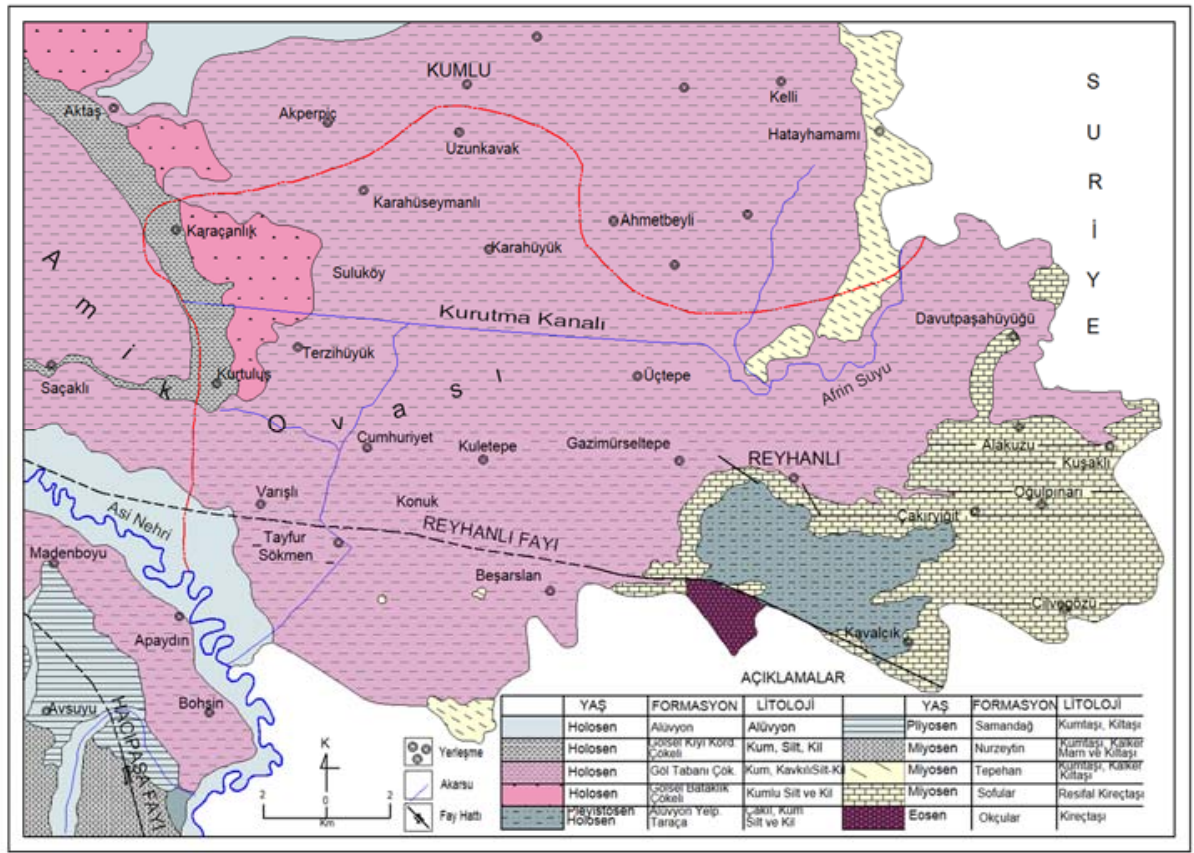

Şekil 2. Reyhanlı İlçesi'nin jeoloji haritası (MTA, 2002).

Figure 2. Geological map of Reyhanlı district (MTA, 2002).

oranının daha fazla olduğu saptanmıştır. Çok belirgin köşeli kırılma yüzeyi veren resifal kalkerleri bol çimentolu sağlam bir yapıdadır. Bol gözenekli, kırılma yüzeyi pürüzlü, belirgin katmanlı bir diziliş gösteren bu formasyonun yüzeyinde (Yıldız ve Taptık, 2003) küçük çaplı erime çukurları ortaya çıkmıştır.

Miyosen yaşlı Tepehan Formasyonu kumtaşı, kalker ve kiltaşından meydana gelmektedir. Sahanın kuzeydoğusunu Türkiye ile Suriye arasında K-G uzanışlı bir kuşak oluşturmakta ve buradan itibaren KD-GB doğrultulu çizilecek bir hat üzerinde birbirinden uzak ve küçük parçalar şeklinde lokal olarak görülmektedir. Tepehan Formasyonu, Sofular (alt) ile Nurzeytin (üst) formasyonları arasında geçişli olarak yer almaktadır.

Kuvaterner dolguları, Amik Ovası'nda görülmektedir. Çimentolanma yok denecek kadar azdır. Kalınlığı maksimum 20 m'ye kadar ulaşabilen Kuvaterner dolgularının bileşenleri kum, kil ve kırıntılı malzemelerden meydana gelmektedir (Yıldız ve Taptık, 2003).

Reyhanlı İlçesi, genellikle basık bir topografya oluşturan ova ve platolardan meydana gelen yeryüzü şekillerine sahiptir. Amik Ovası'nın doğusunda yer alan ve bu ovadan 100-150 m yüksekliğindeki bir fayla ayrılan Reyhanlı Ovası bulunmaktadır. Reyhanlı Ovası'nın da doğusunda yükselen ikinci bir fayla da platolar kuşağına geçilmektedir. Sahada yer alan araziler fay tektoniği ile şekillendiği için topografyada ani yükselti farklılıkları ortaya çıkmaktadır. Böylece batıdan doğuya doğru eğim arttığı için akarsuların akışı genellikle ova tabanlarına doğru olmaktadır (Şekil 3).
Bundan dolayı Amik Ovası çevredeki suların toplandığı bir sahaya karşılık gelmektedir.

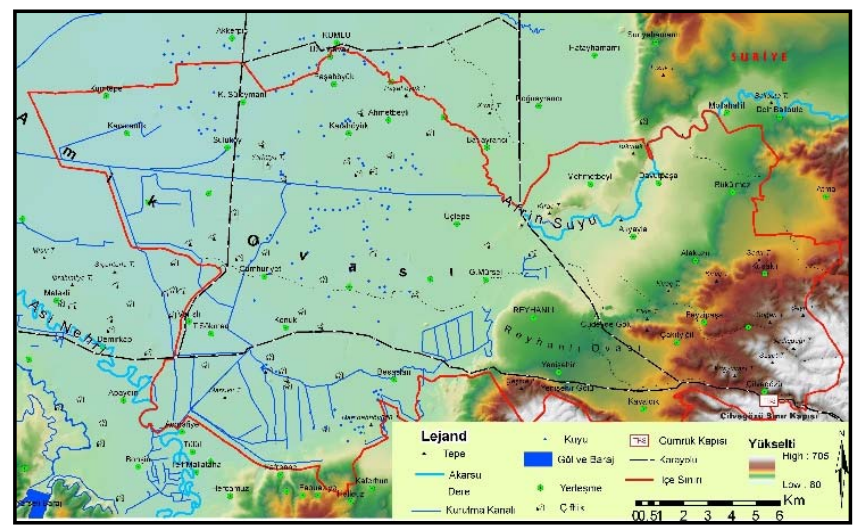

Şekil 3. Reyhanlı İlçesi'nin fiziki haritası.

Figure 3. Physical map of the Reyhanlı district.

Thornthwaite yöntemine göre Reyhanlı'da yarı nemli-yarı kurak, orta sıcaklıkta (mezotermal), su fazlası kış mevsiminde ve orta derecede olan, okyanus iklimine yakın ( $C 1 B^{\prime} 4 s b^{\prime} 3$ ) bir iklim görülmektedir (Şekil 4). Sıcaklığa göre yapılan iklim tasnifinde Reyhanlı, denizel iklime daha yatkındır. Ancak nemlilik açısından yapılan iklim tasnifin de ise Reyhanlı yarı kurak-az nemli bir iklim tipi ortaya çıkmaktadır. Reyhanlı yağışın önemli bir bölümünü kış mevsiminde aldığı için aralık-mart ayları arasında geçen sürede su fazlası meydana gelmektedir. Reyhanlı'da Mart ayından itibaren sıcaklığın artması ve yağışın azalması 
nedeniyle toprakta bulunan su Mayıs ayına kadar bütünüyle harcanır ve su açığı Ekim ayının sonuna kadar devam etmektedir. Yaz kuraklığı nedeniyle Reyhanlı topraklarında uzun süren bir su noksanı vardır. Bu noksanlık toprak içinde gerçekleşmesi gereken kimyasal olayları büyük ölçüde kesintiye uğratmaktadır.

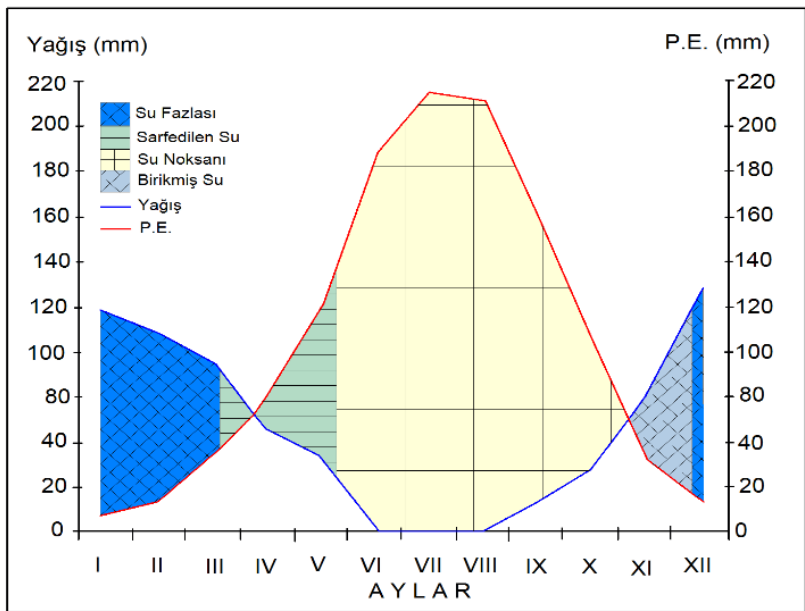

Şekil 4. Thornthwaite metoduna göre Reyhanlı'nın su bilançosu diyagramı.

Figure 4. Water balance diagram of Reyhanlı according to Thornthwaite method.

\section{METOT ve YÖNTEM}

Çalışmada 1/25.000 ölçeli topografya haritaları (P36b4, P36b3, P36c2, P36c1, p37a4, P37a3, P37d1, P37d2) bilgisayar ortamında birleştirilerek sayısal yükseklik modeli üretilmiştir. Bu yükseklik modeli üzerine toprak haritası çakıştırılarak toprak tiplerine göre iletkenlik ölçümünün yapılacağı noktalar belirlenmiştir. Ancak daha net sonuçlar elde etmek amacıyla 3'er km aralıklara denk gelecek şekilde ilk belirlenen numune ölçüm yerlerine yeni noktalar ilave edilmiştir. Böylece 214 noktada ölçümün yapılacağı kararlaştırılmıştır (Şekil 5).

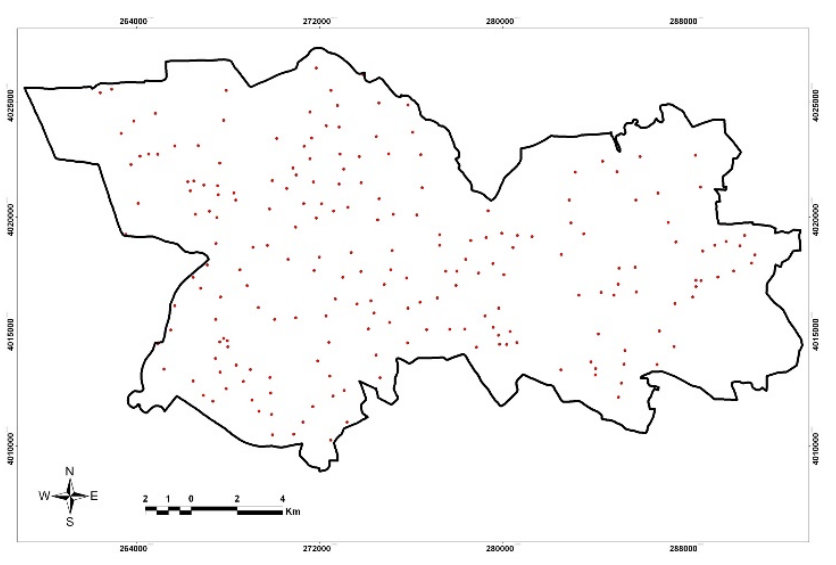

Şekil 5. Arazi çalışmalarında ölçüm yapılan noktalar.

Figure 5. Map of measured points through field studies.

Belirlenen noktalarda el tipi AT WET Sensor aleti kullanılarak ölçümler yapıldı. Topraktaki tuzun erimesi ve cihaz tarafından daha hassas ölçümlerin gerçekleştirilmesi için yağışlar sonrası arazi çalışması yapıldı. Her noktanın tuzluluk değeriyle birlikte Global Positioning Systems (GPS) cihazıyla $X$ ve $Y$ koordinat değerleri kaydedildi. Ölçüm sonuçları Coğrafi Bilgi Sistemleri (CBS) ortamında nokta haritaya dönüştürüldü. Kriging interpolasyon tekniği kullanılarak çalışma sahasının tuzluluk haritası üretildi ve dört ayrı kategori halinde tuzluluk sınıflandırılması yapıldı. Tuzluluk haritasından alanlara yönelik raporlar alınarak grafikler elde edildi. Tuzluluğun yüksek olduğu alanlarda tuzluluğun nedenleri arazi çalışmalarıyla tespit edilmeye çalışıldı.

\section{REYHANLI ILÇESI TOPRAKLARI ve TUZLANMA PROBLEMLERI}

Toprak, kayaçların fiziksel ayrışması ve kimyasal olarak çözülmesi sonucu oluşan, bitkileri barındıran ve canlılara besin kaynağı sağlayan, kara yüzeyini birkaç $\mathrm{mm}$. ile birkaç metre kalınlığında saran ve bünyesinden çeşitli minareler, canlı organizmalar, organik maddeler, hava ve su bulunduran bir örtüdür (Atalay, 2004). Toprağın oluşumunda etkili olan faktörlere bağlı olarak farklı toprak tipleri ortaya çıkmıştır.

Ülkemizde çorak (tuzlu ve alkali) topraklar çeşitli yollarla meydana gelmektedir. Toprağın derinliklerinde bulunan tuzlu veya alkali materyalin aşınmayla yüzeye çıkması veya tuzlu maddelerin kapilariteyle yükselerek toprak yüzeyine yakın kesimlerde birikmektedir. (Atalay, 2006). Reyhanlı'da eski göl tabanında jips minerali kapilariteyle yüzeye kadar çıkmakta ve toprağın tuzlanması üzerinde etkili olmaktadır.

Toprakların tuzlanma ve alkalileşmesini sulama, drenaj, toprak özellikleri, topografya ve iklim gibi etmenler önemli ölçüde etkilemektedir. Drenaj sorunu beraberinde tuzlulukalkalilik gibi çevresel sorunları da getirmektir. Harran, Amik, Konya ve Aşağı Seyhan ovaları başta olmak üzere Türkiye'de, sulamaya uygun arazilerin yaklaşık \% 32.5'ine denk gelen 1.5 milyon hektarda tuzluluk ve alkalilik sorunu bulunmaktadır (Kamber vd., 2012).

Reyhanlı'da toprakların oluşması üzerinde iklim, ana kaya, yükselti, eğim, bakı, drenaj özelliklerinin etkisi büyüktür. Bu faktörlere bağıı olarak Reyhanlı yöresinde klasik sınıflandırmaya göre iki büyük gruba ait topraklar yayılış göstermektedir. Doğusu, Reyhanlı İlçesi'nin sınırlarına giren Amik Ovası'nda alüvyonlar geniş yer kaplamaktadır. Bu nedenle ilçenin batısı toprak özellikleri açısından yeknesak bir özellik göstermektedir. Toprak profilleri ve toprak analizlerine göre Amik Ovası'nı oluşturan topraklar fiziksel ve kimyasal özellikleri açısından büyük benzerlikler göstermektedir. Ancak yapı ve topografyanın büyük oranda değiştiği Reyhanlı Ovası'nın doğusunda ise kırmızı Akdeniz toprakları, kırmızı kahverengi Akdeniz toprakları, kolüvyal topraklar ve kahverengi orman toprakları gibi farklı toprak tipleri ortaya çıkmıştır.

İklim özellikleri ve coğrafi unsurlar bir yerde toprağın oluşmasında önemli olan faktörlerdir. Fiziksel ve kimyasal ayrışmanın meydana gelmesi, bitki örtüsünün gelişmesi, toprağın yıkanması ile organik faaliyetler hep iklime bağı 
unsurlardır. Ancak farklı toprak tiplerinin meydana gelmesinde sahanın topoğrafik özellikleri de etkili olmuştur.

Eğimin azaldığı yerlerde derin topraklar, eğimin arttığı yerlerde sığ topraklar oluşmaktadır. Buna göre Amik Ovası'nın büyük bir bölümünde eğim \% 0-2, Kumtepe, Karacanlık, Kurtuluş ve Terzihöyük'te \% 2-6 olduğu için derin alüvyal ve kolüvyal topraklar, platolar sahasında eğim \% 12-20 arasında olduğu için sığ kırmızı Akdeniz toprakları ile yer yer kahverengi Akdeniz toprakları oluşmuştur.

Toprağın tekstür yapısı; toprağın elastiklik, sertlik, geçirgenlik, kuraklılık ve verimlilik gibi özelliklerini etkilemektedir (Atalay, 2006). Inceleme alanı topraklarının tekstürel özellikleri Kılıç vd. (2008) tarafından yapılan analiz sonuçları dikkate alınarak açıklanmaya çalışılmıştır (Şekil 6). Buna göre Reyhanlı ilçesi'nde yer alan alüvyal toprakların hemen hepsi killi bir tekstüre sahiptir. Bu nedenle bünyeleri ağır olup, toprakların su tutma kapasitesi fazla, havalanma ve geçirgenliği iyi değildir. Taban su seviyesi yüksek olduğu için drenajı bozuktur. Ancak sahada yapılan yoğun tarımsal faaliyetlerden dolayı organik madde miktarı bakımından zengindir. Organik madde içeriği bakımından en zengin olan toprakların (\% 4'den daha fazla) başında Reyhanlı ve Beşarsalan Köyü çevresi gelmektedir.

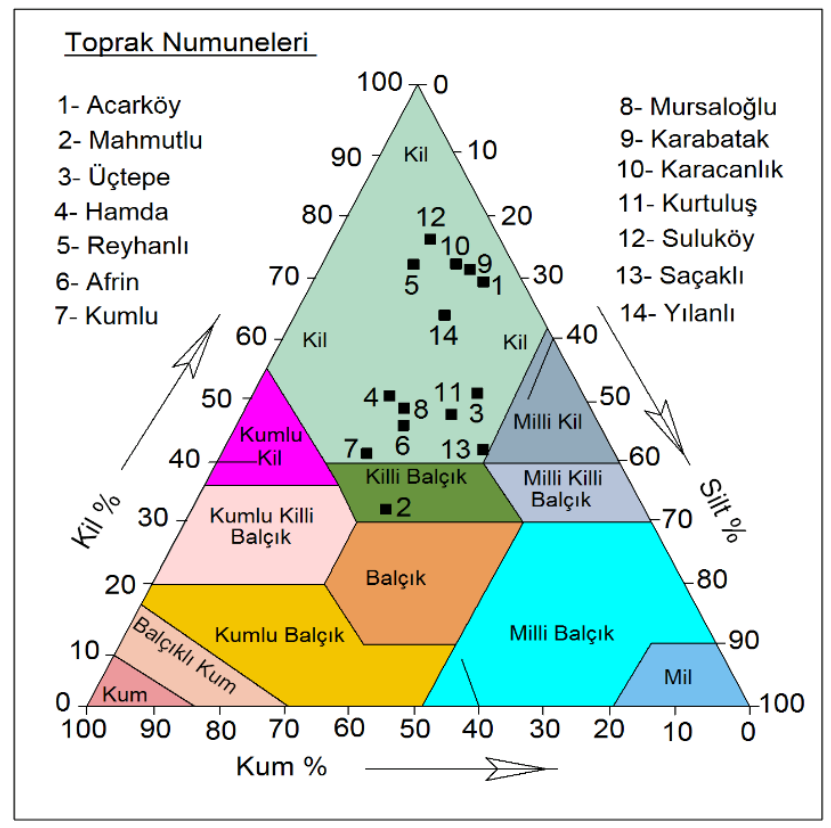

Şekil 6. Toprak tekstürü sınıflandırma üçgenine göre Reyhanlı'nın alüvyal toprakları (Kılıç vd., 2008 verileri kullanılmıştır).

Figure 6. Distribution of aluvial series in Reyhanlı according to classification soil texture classification (using data from Kılıç et al., 2008).

Amik Ovası'nda bozuk bir drenajının görüldüğü sahalarda yapılan hatalı arazi kullanımları toprakta tuzun birikmesine neden olmaktadır. Amik Ovası'nın doğu kesiminde yayılış gösteren terra-rossa toprakları yumrulu bitkilerden olan patates tarımına çok elverişlidir. Ancak patates tarımından yüksek verimin sağlanabilmesi için sulamaya ihtiyaç duyulmaktadır. Patates tarımı tamamen ticari amaçlara yönelik olduğu için aşırı sulama, gübreleme ve ilaç kullanımı yapılmaktadır. Bu şekilde yapılan yanlış kullanımlar toprağın bünyesinde tuz minerallerinin birikmesine yol açmaktadır.

Toprak solüsyonundaki tuz miktarı bitkinin yetişmesini engelleyen önemli bir olaydır. Toprakta bitkinin gelişmesini olumsuz yönde etkileyecek miktarda tuz varsa bu toprak tuzlu sayılmaktadır. Tuzluluğun ölçüsü toprak içindeki tuz miktarı ya da toprak bileşimindeki elektriksel geçirgenlikle ifade edilmektedir ve ölçü birimi milimos "mmos" dur. Genellikle elektriksel geçirgenliği 4 mmos'dan yüksek olan topraklar tuzlu olarak tarif edilmektedir. Tuzluluk 2 mmos'u aşınca etkisini göstermeye başlamaktadır (Genç ve Tükel, 1989). Amik Ovası'nın ayrıntılı toprak sınıflandırmasını yapan Şeref ve arkadaşlarının çalışmasına göre $\mathrm{Na}$ içermeyen ve ECe> $4 \mathrm{dS} / \mathrm{m}$ olan toprak serisine rastlanmamıştır (Kılıç vd., 2008). Çünkü Şeref ve arkadaşlarının çalışması Reyhanlı İlçesi'nin doğusunu kapsamamaktadır. Zaten yaptığımız analiz sonuçlarına göre Reyhanlı İlçesi'nde tuzluluğun en yüksek olduğu sahayı ilçenin kuzeydoğusundaki topraklar oluşturmaktadır.

Çalışmada tuzluluk sınıflandırılması 1-2 mmos, 2.1-3 mmos, 3.1-4 mmos, 4.1-5 mmos olmak üzere dört gruba ayrılmıştır. Toprak gözenek suyu iletkenliği 1-2 mmos olan ve $76,9 \mathrm{~km}^{2}$ lik alan kaplayan araziler ilçe yüzölçümünün \%21,3'nü oluşturmaktadır (Tablo 1, Şekil 7). Tuzluluğu en az olan yerlerin ilçenin doğusu ile batısında görülmesi bu sahalarda drenaj problemlerinin olmaması ile açıklanabilir (Şekil 8).

Tablo 1. Reyhanlı'da Tuzluluk sınıfları (Nisan2012).

Table 1. Distribution of area according to salinity (April 2012).

\begin{tabular}{|c|c|c|c|}
\hline Derece & Toprak Tuzluluğu (mmos) & Alan $\left(\mathrm{km}^{2}\right)$ & $\%$ \\
\hline 1 & $4.1-5$ & 10.9 & 3 \\
\hline 2 & $3.1-4$ & 45.6 & 12.6 \\
\hline 3 & $2.1-3$ & 228.5 & 63.1 \\
\hline 4 & $1-2$ & 76.9 & 21.3 \\
\hline \multicolumn{2}{|c|}{ Toplam } & 362 & 100 \\
\hline
\end{tabular}

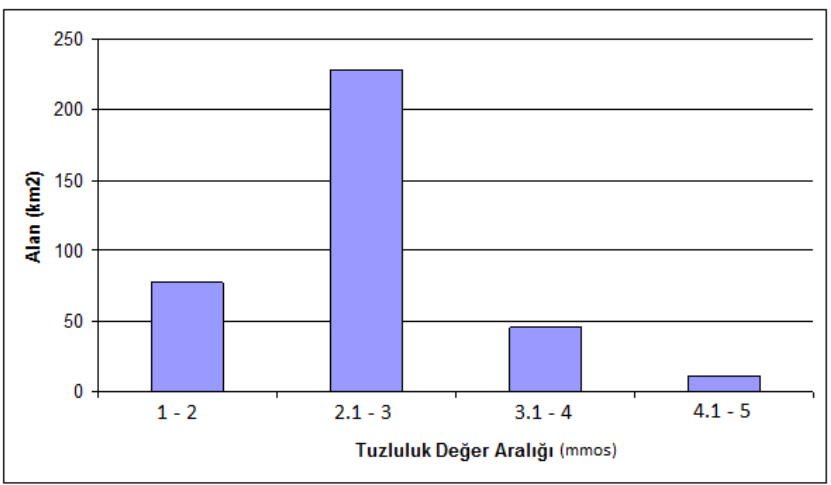

Şekil 7. Tuzluluk sınıflarına göre alan dağııışı.

Figure 7. Distribution of area according to salinity categories. 
İlçenin doğusunu oluşturan Cilvegözü, Çakıryiğit, Oğulpınarı Fevzipaşa köylerini içine alan saha dalgalı ve parçalı arazilerden oluşmaktadır. Burada tarım arazileri çok az olup, tarımsal faaliyetler polye, uvala ve vadi tabanlarında ve genellikle kuru tarım şeklinde tahıl tarımı yapılmaktadır. Toprak gözenek suyu iletkenliğinin en düşük olduğu platonun (Tizin Platosu) dışa akışı vardır. İlkbahar aylarında kapilarite ile yüzeye tuz yükselse bile yüzeysel akışla birlikte ortamdan uzaklaşmaktadır. İlçenin batısında yer alan Konuk, Beşarslan ve Cumhuriyet köyleri çevrelerinde tuzluluğun düşük olmasında açılan drenaj kanallarının suyu drene etmesi ile ilgilidir.

Toprak gözenek suyu iletkenliği 2.1-3 mmos olan ve 63.1 $\mathrm{km}^{2}$ lik bir alan kaplayan üçüncü gruptaki araziler ilçenin \% 63,1'ine karşılık gelmektedir (Tablo 1, Şekil 7,). Beşaslan, Konuk, Cumhuriyet, Suluköy ve Terzihöyük köy arazileri yaptığımız tuzluluk sınıflandırmasına göre III. grubu oluşturmaktadır (Şekil 8). Toprak gözenek suyu iletkenliği en düşük olan bu üçüncü sahada taban suyu çok yüksektir. İlkbahar aylarından taban suyu yüzeye kadar çıkarak, yer yer bataklıklar oluşturmaktadır. Ancak bu alandaki kuyularla Reyhanlı ve bazı köylerin içme suyu karşılandığı için taban suyunun dinamik seviyesi hızla değişmektedir. Yoğun tarımsal faaliyetlerine rağmen toprağa verilen gübre ve ilaçlar toprakta birikmeyip, taban suyunun seviye değişimine uyarak daha alt katmanlara ulaşmaktadır. Bu çevrelerde iletkenliğin çok düşük çıkmasında Hatay Tarım İşletme Müdürlüğü (TiGEM) ve Mustafa Kemal Üniversitesi ait çiftliklerde münavebeli olarak yapılan tarımın da büyük bir payı vardır.

Toprak gözenek suyu iletkenliği dolayısıyla tuzluluğu 3.14 mmos olan araziler, $45.6 \mathrm{~km}^{2}$ lik bir alan oluşturmakta ve bu sahalar ilçenin \%12,6'sına denk gelmektedir (Tablo 1, Şekil 7). Toprak gözenek suyu iletkenliği ikinci derecede olan sahalar ova ile platoların ya kontak sahasında yada eski göl tabanında yer almaktadır. Gölsel tortullarda tuz depolarının olduğu bilinmektedir. Bu depolar içinde açılan kuyularda adeta tuzlu su çıkmaktadır. Kontak sahalara daha yükseklerden süzülerek gelen suların toplama sahası olduğu için buralarda da tuz mineralleri artış göstermektedir.

Toprak gözenek suyu iletkenliği ikinci derecede yüksek olan sahalar Kurtuluş, Kumtepe, Ahmetbeyli, Davutpaşa ve Kavalcık köylerini içine almaktadır (Şekil 8). Ancak birbirinde farklı parçalar halinde olan tuzluluğun birbirinden farklı sebepleri vardır.

Zor-Şengül tarafında yapılan bir çalışmada Kazkeli Köyü yakınlarında 5-7, 20-22, 36-38 m seviyelerinde jips mercekleri tespit edilmiştir. Yeraltı su seviyesinin yükseldiği dönemlerde jipsli mineralleri kapilarite ile yüzeye kadar yükselerek, tuz konsantrasyonunu arttırmaktadır (Zor ve Şengün, 2002). Kurtuluş ve Kumtepe'de iletkenliğin yüksek olması göl tabanı ile ilgilidir. Çünkü bu çevrelerde 15-50 m derinliğinde tuzlu su çıkmaktadır. Ancak bu sularla yapılan sulamalardan sonra toprak beyaz ve kristal bir renk almakta ve toprak sertleşmektedir. Yörede "kötü kuyu" olarak nitelendirilen ve suyu tuzlu olan bu kuyular bir süre sonra kapatılmaktadır. Ancak daha sonra 150-200 m derinliğinde yeni kuyular açılmaktadır. Derin kuyuların tuz oranı düşük olduğu için sulama suyu olarak bu kuyulardan faydalanılmaktadır. Derin kuyulardan aşırı bir biçimde kullanımından kaynaklanan bazı sorunlar oluşmaktadır. Şöyle ki salma olarak verilen su, belli bir derinliğe kadar sızdıktan sonra kapilarite ile dipteki tuzları yüzeye taşımaktadır. Aşırı ve yanlış sulama teknikleriyle yapılan sulamalar sonucu bu çevredeki toprakların önemli bir kısmı beyaz alkali topraklara benzemektedir.

Tuzluluğun 3.1-4 mmos olduğu bir başka yer, Afrin Suyu yatağında bulunan Ahmetbeyli Köyü (Şekil 8)'dür. Bu köyde pamuk ve buğday tarımı yoğun bir şekilde yapılmaktadır. Sulama suyu olarak Afrin ve yeraltı suyu kullanılmaktadır. Buradaki tuzlanmanın asıl sebebi sulama suyudur. Çünkü Afrin Suyu'na yoğun olarak evsel ve sanayi atık suyu karışmaktadır. Hatta Afrin Suyu'nun akış gösterdiği dönemlerde suyun rengi siyaha yakındır.

Tuzluluğun 3,1-4 mmos arasında olduğu bir başka yer de Davutpaşa Köyü (Şekil 8)'dür. Buradaki arazilerin büyük bir kısmı başta patates olmak üzere işletmek amacıyla çeşitli firmalara kiraya verilmektedir. Firmalar bu arazilerden aynı parsele 4-5 yıl patates ekimi yapmaktadır. Tarım arazilerinden yüksek oranda kar elde etmek amacıyla tarım arazilerine yüksek oranda su, gübre ve tarımsal ilaçlar vermektedir. Bu durum toprağın kimyasal yapısına önemli ölçüde zarar verdiği gibi toprağın tuzluluğunu da arttırmaktadır.

Toprak tuzluluğunun artışında taban suyunun da etkisi vardır. Davutpaşa, Alakuzu ve Kuşaklı köyleri arasında kalan saha Amik Ovası́nın doğusunda yer almasına karşın, oluşumu bu ovadan faklılık göstermektedir. Alakuzu Polyesi olarak adlandırılan Davutpaşa, Alakuzu ve Kuşaklı köyleri çevresinde uzanan bu saha, fayların geometrik olarak çakışması ile oluşmuş ve Amik Ovası'ndan yaklaşık 200 m daha yükseklikte bulunmaktadır. Polye tabanı terra-rossa toprakları ile kaplı olup, kapalı bir depresyonu oluşturmaktadır. Doğal ortamın özellikleri yanında yanlış arazi kullanımı, aşırı sulama ve gübreleme sonucu tuzluluk problemi ortaya çıkmaktadır.

Tuzluluğun 3,1-4 mmos arasında olduğu bir diğer saha, Kavalçık Köyü çevresinde, Suriye'den gelen derelerin oluşturduğu birikinti yelpazeleri üzerinde gelişen topraklardır. Çevredeki araziler Orta Miyosen döneminde oluşan resifal kireçtaşları üzerinde gelişmiştir. Bu araziler üzerinde toplanan sulardan dolayı tuzluluğun artmış olabileceği ihtimali güçlüdür.

Tuzluluğun en yüksek olduğu topraklar Reyhanlı́nın kuzeydoğusu olup, tuzluluk 4,1-5 mmos arasındadır (Şekil 8). Buradaki tuzluluğun sebepleri Davutpaşa Köyü çevresinde görülen tuzluluğun sebeplerine benzemektedir. Çünkü Davutpaşa, Alakuzu, Bükülmez ve Kuşaklı köyleri çevresinde çoğunlukla patates tarımı yapılmaktadır. Araziyi kiralayan firmaların araziden yüksek oranda faydalanmak istedikleri için aşırı sulama, gübreleme ve ilaç kullanımı yapılmaktadır. Ancak doğuya doğru tuzluluğun artması Orta Miyosen serilerine yaklaşıldığını göstermektedir. 


\section{SONUÇ ve ÖNERILER}

Reyhanlı'da 10,9 km² lik bir alanda tuzlanma başlamıştır. Tuzlanmanın giderek yaygınlaşmasını önlemek amacıyla ıslah çalışmalarının yapılması gerekmektedir. Islah çalışmaları arasında münavebeli tarımla birlikte topraktan tuz çeken bitkilerin tarımına önem verilmelidir. Tuzlanmanın baş gösterdiği sahalarda arpa, çayır ve mera

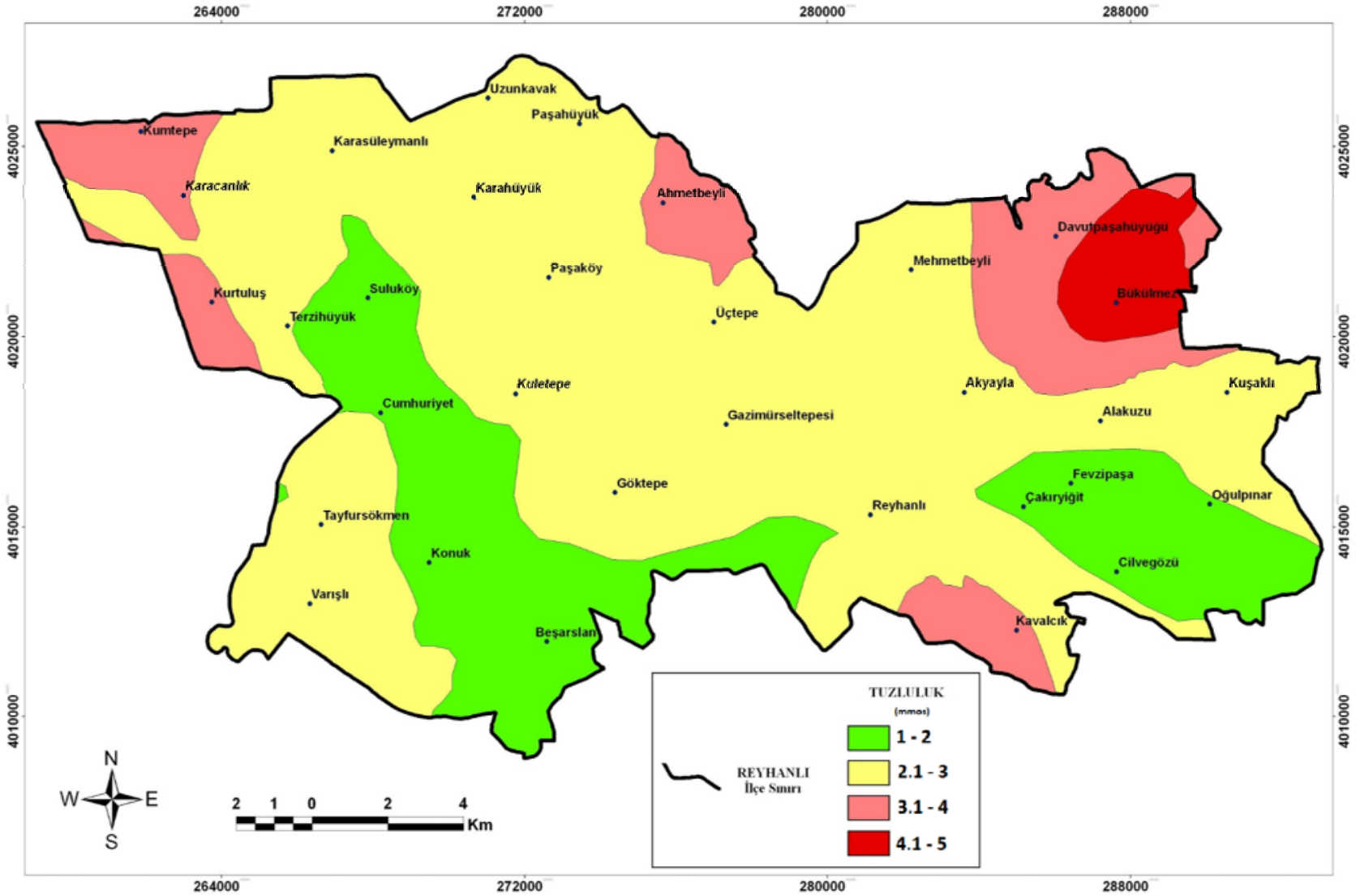

Şekil 8. Reyhanlı İlçesinin tuzluluk haritası.

Figure 8. Salinity map of Reyhanlı district.

bitkilerinin yetiştirilmesi sağlanmalıdır. Çünkü birçok çayır mera yem bitkisi diğer kültür bitkilerinin yetişemeyeceğ kadar yüksek tuzluortamlarda yetişebilme özelliğine sahiptir.

Tuzlu toprakların iyileştirilmesinde başvurulan yöntemlerden biri de biyolojik iyileştirme yöntemidir. Bitkiler toprak geçirgenliğini artırarak; solunum sırasında karbondioksitin açığa çıkmasını sağlayarak; gölgeleme etkileri ile toprak yüzeyinden buharlaşmayı azaltıp suyun yukarı doğru hareketi ile yüzey tuzlarının birikimini azaltarak, sağlıklı sonuçlar or

\section{KAYNAKLAR}

Akalan, ì. (1992). Türkiye'nin Toprak Kaynakları, Bunların Sorunları ve Çözüm Yolları, Ankara Üniversitesi, Türkiye Coğrafyası Uygulama Merkezi Dergisi, Sayı: 1, Ankara

Anonim, (1973). "TOPRAKSU Genel Müdürlüğü il Toprak Kaynağı Envanter Raporları", Ankara. taya çıkmaktadır (Sönmez, 1990). Avcıoğlu, 1990 yılında yayınladığı çalışmada elektriksel geçirgenlik değeri 4 mmos'un üzerinde olan sahaların yeniden tarıma kazandırılmasını sağlamak amacıyla okaliptüs türlerinden olan E. Camaldulensis ile ağaçlandırılmasını önermektedir (Avcıoğlu, 1990). Tuzluluğun baş gösterdiği sahalarda ıslah çalışmaları yapılmalı, münavebeli tarım sistemi uygulanmalı, ağaçlandırma çalışmalarına önem verilmelidir.

Atalay, ì. (2004). Türkiye Coğrafyası ve Jeopolitiği, Meta Basım Matbaacılık Hizmetleri, Bornova, İzmir.

Atalay, i. (2006). Toprak Oluşumu, Sınıflandırılması ve Coğrafyası, Meta Basım Matbaacılık Hizmetleri, İzmir

Atasoy, A. (2012). Reyhanlı Ilçesi'nin Coğrafyası, Mustafa Kemal Üniversitesi Yayınları No:36, ISBN: 978-9757989-35-6, Antakya. 
Avcıoğlu, E. (1990). "Okaliptüs: Yetiştiriciliği, İ̧̧letmesi, Kavak ve Hızlı Gelişen Yabancı Tür Orman Ağaçları", Araştırma Enstitüsü Dergisi, 1990/1-21-49, izmit.

Dinç, U., Sarı, M. Şenol, S., Kapur, S., Sayın, M., Derici, M.R., Çavuş̧gil, V., Gök, M., Aydın, M., Ekinci, H., Ağca, N., Schlicting, E. (1990). Çukurova Bölgesi Toprakları, Çukurova Üniversitesi, Ziraat Fakültesi Yardımcı Ders Kitabı No: 26,171, Adana.

Dougherty, T. C. and Hall, A. W. (1995). Environmental Impact Assessment of Irrigation and Drainage Projects, FAO Irrigation and Drainage Paper 53/74, Rome.

Genç, I. ve Tükel, T. (1989). Tarım Ekolojisi, Çukurova Üniversitesi Ziraat Fakültesi Ders Notu No:29. Ofset ve Teksir Atölyesi,146. Adana.

Kanber, R., Çullu, M. A., Kendirli, B., Antepli S., Nazım, Y. (2012). "Sulama, Drenaj ve Tuzluluk" http: //www. zmo.org.tr/resimler/ekler/bf22ab286e2ad49 _ek.pdf?tipi=14andsube (Son Erişim:11.12.2012, saat: 15:05).

Kılıç, Ş., Ağca, N., Karanlık, S., Şenol, S., Aydın, M., Yalçın, M., Çelik, i., Evrendilek, F., Uygur, V., Doğan, K., Aslan, S., Çullu, M.A. (2008). Amik Ovasının Detaylı Toprak Etütleri, Verimlilik Çalışması ve Arazi Kullanım Planlaması, Devlet Planlama Teşkilatı (DPT) Projesi, 2002K 120480.

MTA, (2002). Türkiye Jeoloji Haritası (1/500.000 Ölçekli), Maden Tetkik ve Arama Enstitüsü Basımevi, Ankara.

Sönmez, B., (1990). "Tuzlu ve Sodyumlu Topraklar", Köy Hizmetleri Şanlıurfa Araştırma Enstitüsü, Genel Yayın No: 62, Teknik Yayın No: 17/66 Şanlıurfa.

Yıldız, H., Taptık M.A. (2003). "Hatay Ilinin Jeolojisi”, Doğu Akdeniz Bölge Müdürlüğü, Adana.

Yılmaz, M. (2010), Karapınar Çevresinde Yeraltı Suyu Seviye Değişimlerinin Yaratmış Olduğu Çevre Sorunları, Ankara Üniversitesi Çevrebilimleri Dergisi 2(2), 145163, Ankara

Zor, M., Şengün, M.T. (2002). “Amik Ovasının Hidroğrafik Özelliklerinde Meydana Gelen Değişmeler ve Bunun Sonucunda Ortaya Çıkan Sorunlar", Su Havzalarında Toprak ve Su Kaynaklarının Korunması Geliştirilmesi ve Yönetimi Sempozyumu: 338-343, 18-20 Ekim 2002. Antakya/Hatay. 